\title{
Spatial Analysis of Distribution Patterns of Dengue Hemorrhagic Fever Cases in Banda Aceh
}

\author{
Suwardi, Imran and Muzailin Affan \\ Magister of Disaster Science, Syiah Kuala University, Banda Aceh, Indonesia \\ \{suwardi.unsyiah@gmail.com\}
}

\begin{abstract}
Dengue Hemorrhagic Fever (DHF) is an infectious disease that became the leading cause of death in the tropics and subtropics Countries. Banda Aceh is one of the regions in Indonesia with the high incidence of DHF and the distribution of events per sub-district is still fluctuating, so a study of the spatial relationship of DHF distribution patterns in Banda Aceh is needed. The aim of this study is to determine the spatial relationship of the DHF distribution pattern in Banda Aceh from 2014 to 2016. The study uses the Geographic Information System method with a case study approach. The object of this research is the entire administrative area of Banda Aceh with an analysis unit for all villages in Banda Aceh. The Moran Index Analysis was used to the identification of distribution pattern by means of the Geoda application. The results showed that during the 2014 to 2016 period, the global spatial relationship of DHF incidence among Villages was only found in October and November 2014, while in other months it did not show a spatial relationship at the $95 \%$ significance level. The $\mathrm{z}$ value calculation for October is 2.27 November is 3,80 . The local spatial association of DHF was found the villages where are 6 villages in the high-high cluster, 10 villages in the lowlow cluster, 2 villages in the low-high cluster, and 2 villages in the high-low cluster in the year 2014. Beside that, in the year 2015 there was 1 village in the high-high cluster, 8 villages in the low-low cluster, 5 villages in the low-high cluster, and none in the high-low cluster. Furthermore, in the year 2016 which are 3 villages in the high-high cluster, 4 villages in the low-low cluster, 5 villages in the lowhigh cluster, and that 1 village in the high-low cluster. The local spatial analysis found that villages in the hotspot cluster vary annually.
\end{abstract}

Keywords: DHF, Spatial Patterns, Geographic Information Systems, Moran's Index.

\section{Introduction}

Dengue Hemorrhagic Fever (DHF) is a threat to one-third of the world's population in the tropics and subtropics countries since it's become one of the main causes of death in that area and its occurrence in the last 50 years continues to increase to 30 times [1], [2].

Indonesia is the country with the highest number of DHF Cases in Southeast Asia since 1968 and based on DHF incidence data up to 201, it shows three epidemics peaks, hence it is estimated that the DHF epidemic will happen repeatedly within 9 to 10 years [3].

Banda Aceh is one of the areas that is endemic to DHF with a high DHF cases number. Based on DHF from the year 2012 to 2016, the cases incidence trend fluctuated each year, even though there is a decrease in cases in 2013, yet it shows an increase in 2014, while in 2015 it's decreased and increased again in 2016[4]. 
Research on the distribution of DHF cases conducted by Castillo, et al. Using the Moran Index analysis found that the spatial distribution of the distribution of dengue in Guayaquil City, Ecuador was very high. This shows that the possibility of the spread of dengue infection is higher in areas that have contracted dengue infection [5].

The study conducted by Hermansyah [6] found differences in the dispersion patterns of DHF in severely affected tsunami areas with mildly affected tsunami areas. In areas with severely affected was clustered which was allegedly due to the process of residential areas reconstruction.

The mapping of DHF distribution incidence is compulsory in order to perceive the variation in DHF incidence among Villages in Banda Aceh hence the disaster risk reduction can be done by areas. The aim of this study is to determine the spatial relationship of the DHF distribution pattern in Banda Aceh from 2014 to 2016, globally and locally, since there is no many research regarding spatial relationship of village-based DHF distribution in Banda Aceh

\section{Methods}

This study uses the Geographic Information System method with a case study approach, which is to study the dynamics of spatial autocorrelation of DHF events in Villages of Banda Aceh from 2014 to 2016.

The object of this research is the entire administrative area of Banda Aceh which is located between 05o16'15' - 05o36'16" North Latitude dan 95o16'15"-95o22'35" East Longitude with the unit of analysis is 90 Villages in Banda Aceh. The data used in this study are secondary data obtained from the Banda Aceh Health Office. The data are the incidence of DHF in Banda Aceh in each villages in the year 2014, 2015 and 2016.

Data analysis uses the statistics of Moran's Index autocorrelation and Local Indicator of Spatial Association (LISA). Analysis of Moran's Index which is to determine the existence of a spatial relationship between DHF cases globally. The equation of the Moran's index is as follows the equation 1 ;

$$
\begin{gathered}
\boldsymbol{I}=\frac{\sum_{i} \sum_{j} \boldsymbol{w}_{\boldsymbol{i} j}\left(\boldsymbol{X}_{\boldsymbol{i}}-\overline{\boldsymbol{X}}\right)\left(\boldsymbol{X}_{\boldsymbol{j}}-\overline{\boldsymbol{X}}\right)}{\boldsymbol{s}^{2} \sum_{i} \sum_{j} \boldsymbol{w}_{\boldsymbol{i j}}} \ldots \ldots \ldots(1) \\
s^{2}=\frac{\sum_{i=1}^{n}\left(X_{i}-\bar{X}\right)^{2}}{n} \ldots \ldots(2) \\
\bar{X}=\frac{\sum_{i=1}^{n} X_{i}}{n} \ldots \ldots \text { (3) }
\end{gathered}
$$

Where;

$\mathrm{n}$ : the number of observation locations

$\mathrm{X}$ : Mean of Xi

$\mathrm{Xi}$ : Variable value in area $\mathrm{i}$

$\mathrm{Xj}$ : Variable value in area $\mathrm{j}$

Wij: spatial weighting matrix elements, worth 1 if $\mathrm{i}$ and $\mathrm{j}$ are neighbors, and 0 if not neighboring.

LISA analysis aims to detect the presence of local spatial autocorrelations in aggregate by describing Moran's index statistics that contribute to each study area. Operationally, the LISA analysis has two criteria namely first giving an indication of the extent to significant spatial grouping with similar values around the observations and both the total number of LISA values as a proportional global indicator of spatial relations [7]. 
Hypothesis testing uses a $\mathrm{z}$ score, which means if the $\mathrm{z}$ value is greater than 1.96 or smaller than -1.96 indicating that the null hypothesis is rejected at the $95 \%$ significance level. While the distribution pattern can be seen by comparing the index value of Moran (I) with its expected value $(\mathrm{E}(\mathrm{I}))$, that is if $\mathrm{I}>\mathrm{E}(\mathrm{I})$, then the pattern of distribution is clustered. If $\mathrm{I}<\mathrm{E}(\mathrm{I})$, then the distribution pattern is spread (dispersed), and if $\mathrm{I}=\mathrm{E}(\mathrm{I})$, then the pattern of random distribution. The equation to obtain the $\mathrm{z}$ score and expected value are as follows the equation 4 and 5 [8], [9].

$$
\begin{gathered}
z=\frac{I-E(I)}{\sqrt{V(I)}} \ldots \ldots(4) \\
E(I)=\frac{-1}{(n-1)} \ldots \ldots(5)
\end{gathered}
$$

Disease distribution clusters are determined using Moran Scatterplot, which is a linear relationship between the value of the observation area and the value of the neighboring area that is standardized. This relationship is calculated by using the $\mathrm{z}$ score in the area observed on the horizontal axis ( $\mathrm{x}$ ) and the $\mathrm{z}$ score in the neighboring area on the vertical axis. Moran scatterplot shows the classification of DHF distribution clusters, including the high-rise cluster (HH) / hotspot, low-low cluster (LL) / cold spot, low-high (LH) cluster and high-low (HL) cluster.

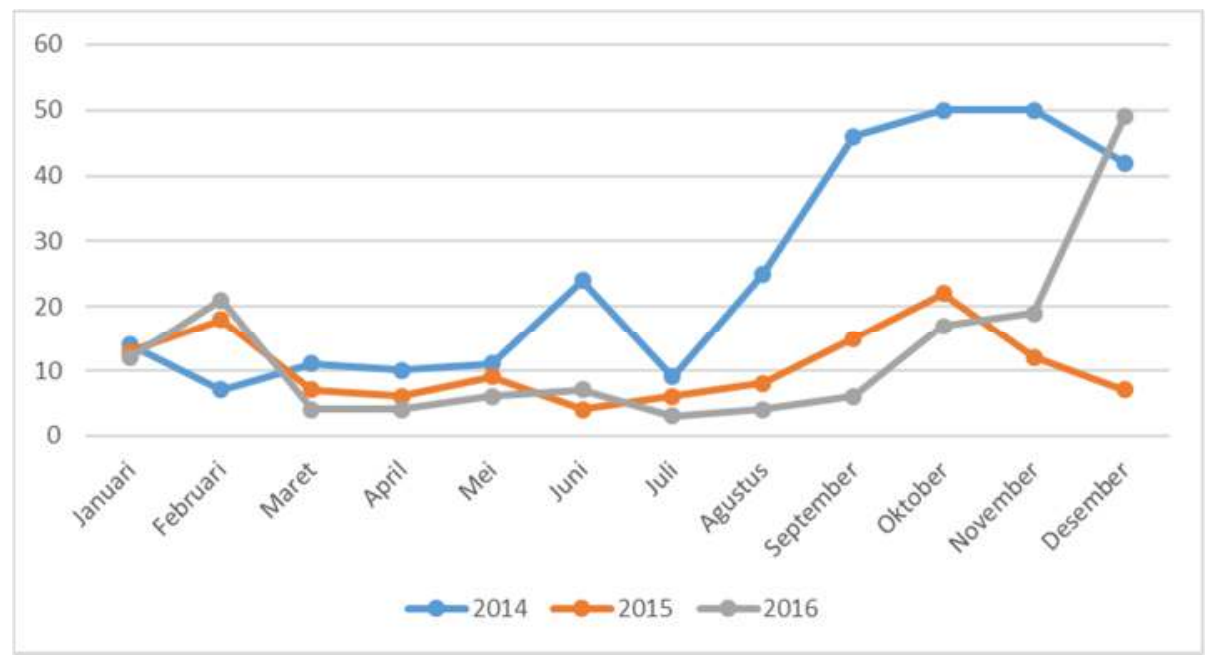

Figure 1. The trend of DHF Cases from 2014 to 2016 

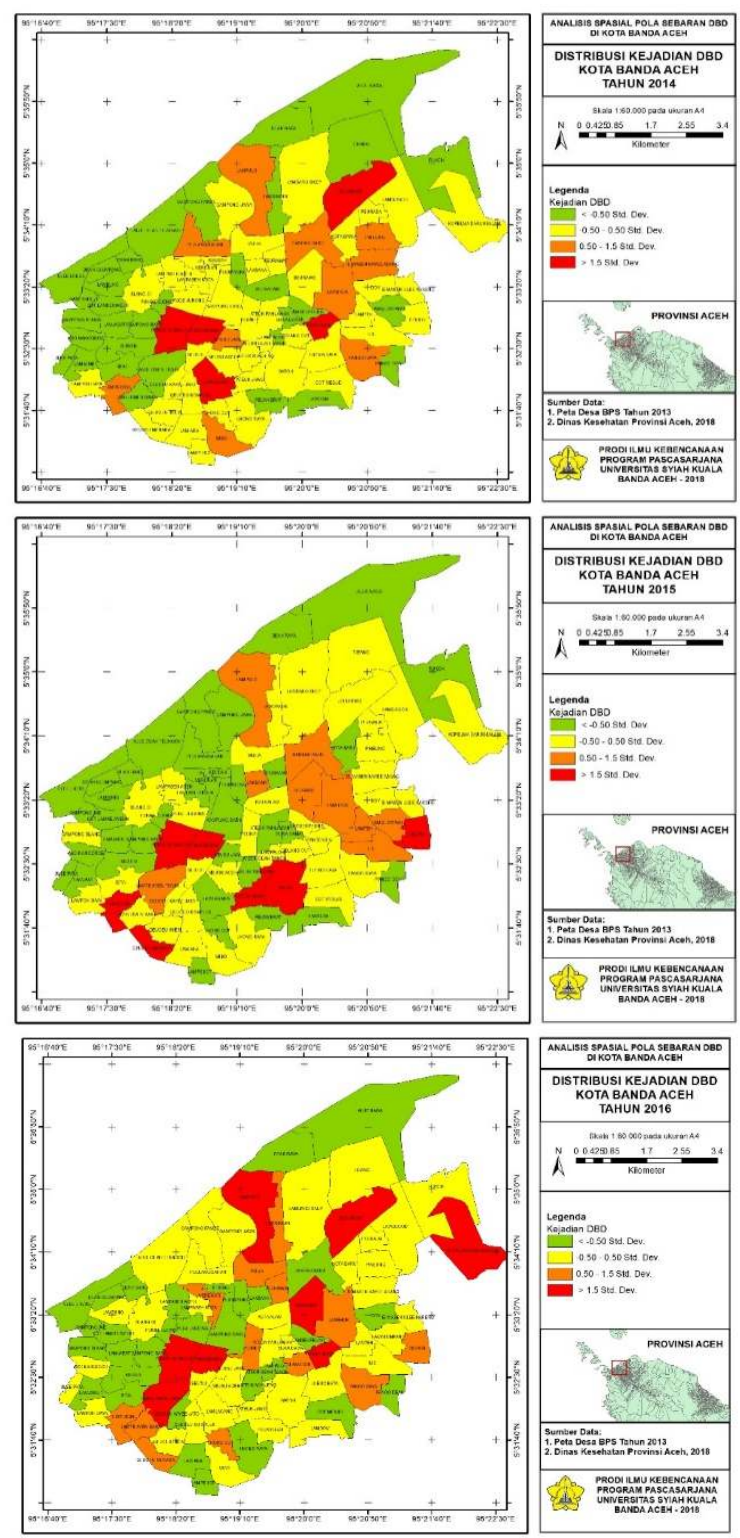

Figure 2. Map of distribution of dengue events in Banda Aceh from 2014 to 2016

The spatial weighting matrix used was queen contiguity and a $95 \%$ confidence interval. The spatial weighting matrix is a matrix that describes the Closeness level between observed areas [8]. Data Processing is done by using the Geoda application. 


\section{Result and Discussion}

DHF events from 2014 to 2016 shows varied fluctuations as illustrated in figure 1 . Distribution of dengue incidence based on the number of times the incidence of DHF in the city of Banda Aceh is shown in figure 2.

Based on figure 1, it is known that the number of DHF events has increased from August to November and there has been a significant decline in December, except in December 2016. The distribution of dengue events shown in figure 3 shows that villages that are directly adjacent to the coast are generally below average.

\section{a. Global distribution pattern}

The results of the Moran index calculation can be observed in table 1. The Moran index value is compared with the value of Expectation E (I) shows a clustered, dispersed or random dispersion pattern. While the statistical test uses the $\mathrm{z}$ value to determine whether $\mathrm{H} 0$ is rejected or not rejected.

Table 1 shows that in October and November 2014 the $z$ value is greater than 1.96, namely in October $\mathrm{z}$ value is 2,272 and in November the $\mathrm{z}$ value is 3.804 . which means that in this month $\mathrm{H} 0$ was rejected or there was a spatial relationship in the distribution of DHF cases in Banda Aceh in October and November 2014. There was a spatial relationship of DHF dispersion in Banda Aceh in October and November 2014 indicating the possibility of a high correlation of DHF cases among Villages in October and November 2014.

The research conducted by [10] in Pekalongan district also shows the results of spatial analysis of the distribution of DHF that is similar, namely there are spatial relationships in certain months, including January, February, July, October, and December. Spatial relationships vary in each sub-district, namely some sub-districts have positive autocorrelation and others have negative autocorrelation.

The high correlation between the incidence of DHF among village is thought to be due to high rainfall rates. Banda Aceh statistical data shows that rainfall rates in October and November 2014 is the highest compared to rainfall rates in other months of the period 2014 to 2016 [11].

Kemenkes RI [12] states that rainfall rates are one of the risk factors for disease transmission that has the potential to cause DHF outbreaks. The high rate of transmission when the rain occurs because during high rainfall rates the places that become breeding places for Aedes Aegypty mosquitoes that were previously not filled with water and cause mosquito eggs to hatch. This will increase the population of the Aedes Aegypty mosquito which will have an impact on increasing transmission and spread of DHF disease.

The study by Perwitasari, Ariati, \& Puspita [13] also concluded that climate change such as rainfall and rainy days affected the incidence of DHF which happen during rainfall which will cause an increase in the amount of standing water hence the mosquito breeding grounds increase.

The distribution pattern of DHF is found by comparing the value of the Moran Index (I) with its expected value (E (I)). If I value is greater than $\mathrm{E}(\mathrm{I})$, then the distribution pattern of DHF is clustered and if the value of $I$ is smaller than $E$ (I) the distribution pattern of DHF dispersed. The distribution pattern of DHF is random if the value of $\mathrm{I}$ is equal to $\mathrm{E}$ (I).

Table 1 explains that the distribution pattern of DHF in January, August, September, October, November and December 2014 tends to be clustered and the rest tends to disperse. The distribution pattern of DHF in 2015 is tended to be in February, April, June, and December, while in January, March, August and September tend to disperse and the rest tend to be random. 
The distribution pattern of DHF in 2016 is tended to cluster in March, April, May, June, and July, and the rest tends to disperse.

Table 1. the results of the Moran index

\begin{tabular}{lllcccccc}
\hline \multirow{2}{*}{ No } & \multirow{2}{*}{ Month } & \multirow{2}{*}{ E(I) } & \multicolumn{2}{c}{$\mathbf{2 0 1 4}$} & \multicolumn{2}{c}{$\mathbf{2 0 1 5}$} & \multicolumn{2}{c}{$\mathbf{2 0 1 6}$} \\
\cline { 4 - 8 } & & I & Zhit & I & Zhit & I & Zhit \\
\hline 1 & January & -0.011 & 0.027 & 0.70 & -0.068 & -1.008 & -0.087 & -1.174 \\
2 & February & 0.011 & -0.069 & -1.006 & 0.101 & 1.669 & 0.019 & 0.487 \\
3 & March & 0.011 & -0.049 & -0.647 & -0.059 & -0.845 & -0.026 & 0.596 \\
4 & April & 0.011 & -0.010 & 0.042 & 0.382 & -0.011 & 0.055 & 1.063 \\
5 & May & 0.011 & -0.001 & 0.019 & 0.003 & 0.242 & 0.087 & 1.447 \\
6 & June & 0.011 & -0.013 & 0.007 & 0.022 & 0.621 & 0.078 & 1.623 \\
7 & July & 0.011 & -0.043 & -0.521 & 0.007 & 0.339 & 0.067 & 1.512 \\
8 & August & 0.011 & 0.081 & 1.407 & -0.045 & -0.552 & -0.046 & -0.583 \\
9 & September & 0.011 & 0.069 & 1.241 & -0.101 & -1.439 & -0.044 & -0.576 \\
10 & October & 0.011 & 0.128 & 2.272 & -0.006 & 0.107 & -0.064 & -0.794 \\
11 & November & 0.011 & 0.227 & 3.804 & 0.017 & 0.492 & -0.027 & -0.236 \\
12 & December & 0.011 & 0.067 & 1.287 & 0.014 & 0.400 & 0.029 & 0.688 \\
\hline
\end{tabular}

The distribution pattern of DHF when calculated with the Moran index value is varied each month, namely, in 2014 it tends to disperse more often, 2015 tends to be random and 2016 tends to be in Clustered more often.

The research on the dispersion of DHF was conducted by Hermansyah [6], in Banda Aceh who used the Closest Neighbor Analysis concluded that the distribution pattern of DHF in Banda Aceh for mild tsunami-affected and non-tsunami affected areas had a random dispersion pattern and only heavy tsunami regions in Clustered.

The distribution pattern of DHF in Jaya Baru Subdistrict, Banda Aceh in 2014 also showed varied dispersion distance of DHF, namely, there were villages that the distance of patients spots is below 100 meters, while in some villages the distance of patients spots is above 1000 meters [14].

Based on the description above it is concluded that the dispersion pattern of DHF in Banda Aceh is not related between one village and another village, but there is a tendency of spatial relationships between villages when rainfall rates are high.

\section{b. Local distribution pattern}

Analysis of the local Moran index of the distribution of DHF in Banda Aceh shows that the number of villages in the hotspot cluster is in 2014 as many as 6 villages, in 2015 as many as 1 village and in 2016 as many as 3 villages. The classification of local DHF distribution patterns can be seen in Figure 3.

Based on Figure 3, villages in the coldspot cluster are in the Meuraxa District area. The Meuraxa sub-district is a region with low population density and settlement density [11], this is thought to be the reason why the Meuraxa Subdistrict area has a low DBD incidence with a lowLow distribution cluster.

Villages in the hotspot cluster vary each year. This is presumably due to the DHF countermeasures carried out in villages with a high incidence of DHF. The Health Office will eradicate and control dengue through "pemberantasan Sarang Nyamuk (PSN)", the "3 M" movement, monitoring larva free numbers and fogging [15]. 

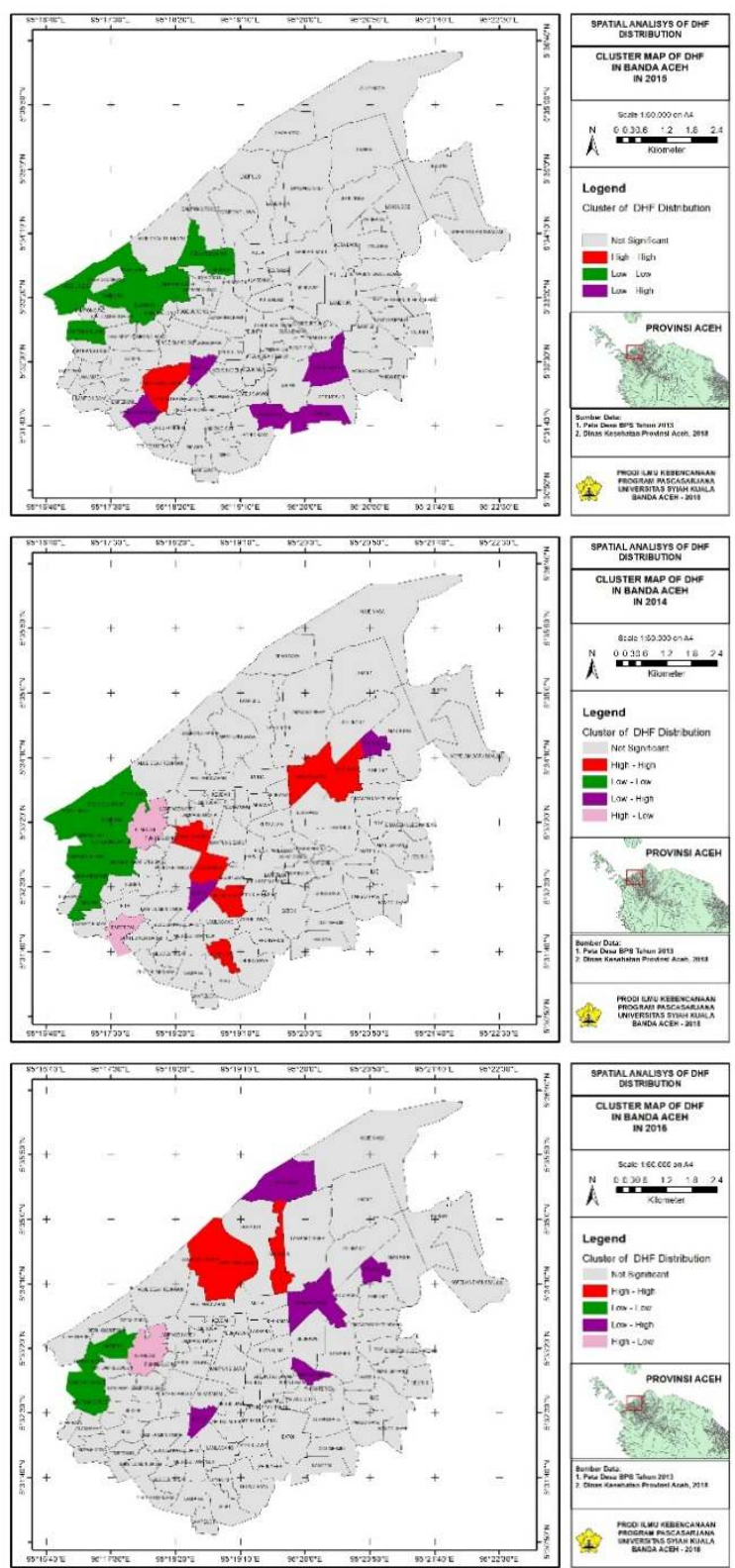

Figure 3. Cluster map of the distribution of DHF in Banda Aceh from 2014 to 2016

Villages located in hotspot clusters are generally located in sub-districts that have a low percentage of households with clean and healthy behavior. In 2014, two villages in Kuta Alam and Baiturrahman Subdistricts were in the hotspot cluster, where based on the health profile of Banda Aceh in 2014, the number of households with clean and healthy behavior was $37 \%$ and $49 \%$ respectively [15]. Whereas in 2016, two villages in Kuta Raja District were in the Hotspot 
cluster, where the number of households with clean and healthy behavior in the sub-district in 2016 was $27.86[16]$.

From the description above, it can be concluded that the population density and population density and the low density of settlements there is a tendency for the number of DHF to be low with a cluster of disease distribution in the cluster of cold spots. While the high population density and households with clean and healthy behavior have contributed to the high incidence of DHF with cluster distribution of hotspot diseases.

\section{Conclusion}

There is a significant spatial relationship in the dispersion pattern of DHF in Banda Aceh in October and November 2014, which was caused by high rainfall rates. Based on the cluster of DHF cases in Banda Aceh in 2014 to 2016, there were two villages that were consistently in the coldspot cluster, one village was consistently located in the low-high cluster and villages in the hotspot cluster vary each year.

\section{REFERENCES}

[1] Centers for Disease Control, "Dengue," Centers for Disease Control, 2016. [Online]. Available: https://www.cdc.gov/dengue/index.html.

[2] World Health Organization, Dengue guidelines for diagnosis, treatment, prevention and control. 2009.

[3] Kemenkes RI, "Buletin jendela epidemiologi: Manajemen demam berdarrah berbasis wilayah," Pusat Data dan Survailans Epidemiologi Kementerian Kesehatan RI, vol. 2, 2010.

[4] Dinas Kesehatan Kota Banda Aceh, "Profil kesehatan kota banda aceh tahun 2015," Kota Banda Aceh, 2016.

[5] K. C. Castillo, B. Körbl, A. Stewart, J. F. Gonzalez, and F. Poncec, “Application of spatial analysis to the examination of dengue fever in Guayaquil, Ecuador," Procedia Environ. Sci., vol. 7, pp. 188-193, 2011.

[6] Hermansyah, "Pola sebaran kasus demam berdarah dengue pasca tsunami di wilayah kota banda aceh," Idea Nurs. J., vol. IV, no. 3, pp. 105-112, 2013.

[7] L. Anselin, "Local indicators of spatial association-LISA," Geogr. Anal., vol. 27, no. 2, pp. 93-115, 1995.

[8] J. Lee and D. W. S. Wong, Statistical analysis with arcview GIS. New York: John Wiley \& Sons, 2001.

[9] T. J. Oyana and F. M. Margai, Spatial analysis statistics, visualization, and computational methods. New York: CRC Press, 2016.

[10] H. Yasin and R. Saputra, "Pemetaan penyakit demam berdarah dengue dengan analisis pola spasial di kabupaten pekalongan," Media Stat., vol. 6, no. 1, 2013.

[11] BPS Kota Banda Aceh, "Kota Banda Aceh Dalam Angka 2017," Banda Aceh, 2017.

[12] Kemenkes R.I, "Modul pengendalian demam berdarah dengue," Kementerian Kesehatan R.I., Jakarta, 2011.

[13] D. Perwitasari, J. Ariati, and T. Puspita, "Kondisi iklim dan pola kejadian demam berdarah dengue di kota yogyakarta tahun 2004-2011," Media Litbangkes, vol. 25, no. 4, pp. 243-248, 2015. 
[14] D. Fakri, Hermansyah, and Nizamuddin, "Analisis pola kasus demam berdarah dengue (DBD) menggunakan metode GIS di kecamatan jaya baru kota banda aceh tahun 2014," J. Ilmu Kebencanaan, vol. 2, no. 3, pp. 9-16, 2015.

[15] Dinas Kesehatan Kota Banda Aceh, "Profil kesehatan kota banda aceh tahun 2014," Banda Aceh, 2015.

[16] Dinas Kesehatan Kota Banda Aceh, "Profil kesehatan kota banda aceh tahun 2016," Kota Banda Aceh, 2017. 